\title{
Interaction of methotrexate, an anticancer agent, with copper(II) ions: coordination pattern, DNA-cleaving properties and cytotoxic studies
}

\author{
Justyna Nagaj · Paulina Kołkowska • Aleksandra Bykowska • \\ Urszula K. Komarnicka • Agnieszka Kyzioł • \\ Małgorzata Jeżowska-Bojczuk
}

Received: 14 February 2014 / Accepted: 7 June 2014/Published online: 4 July 2014

(c) The Author(s) 2014. This article is published with open access at Springerlink.com

\begin{abstract}
The acid-base properties and the $\mathrm{Cu}(\mathrm{II})$ binding processes of methotrexate (MTX) were characterized by selected spectroscopic techniques and potentiometric measurements. The $\mathrm{pH}$ titration data showed that MTX behaves as a triprotic ligand. The deprotonation constants were determined for $\alpha-\mathrm{COOH}$ and $\gamma-\mathrm{COOH}$ groups and $(\mathrm{N} 1) \mathrm{H}^{+}$from the pteridine ring. Taking all the obtained results into consideration, a coordination pattern was proposed. The DNA-cleaving activity and reactive oxygen species (ROS) generation were investigated for both MTX and the $\mathrm{Cu}(\mathrm{II})-\mathrm{MTX}$ system. The complex displayed a promising nuclease activity toward plasmid DNA in the presence of hydrogen peroxide. Interestingly, the induction of ROS, such as hydroxyl radicals, superoxide anions or singlet oxygen, was excluded and a different mechanism of DNA degradation was proposed. As MTX is now commonly used in anticancer therapy i.e. against lung cancer, basic cell-based studies were carried out to establish if its $\mathrm{Cu}$ (II) complex exhibits higher cytotoxic properties than the ligand alone. Activities of both compounds were also tested against colon carcinoma. Moreover, the determined values of $\mathrm{IC}_{50}$ were confronted with the cytotoxic activity of cisplatin.
\end{abstract}

Electronic supplementary material The online version of this article (doi:10.1007/s00044-014-1074-1) contains supplementary material, which is available to authorized users.

J. Nagaj · P. Kołkowska · A. Bykowska

U. K. Komarnicka · M. Jeżowska-Bojczuk $(\bowtie)$

Faculty of Chemistry, University of Wrocław, F. Joliot-Curie 14,

50-383 Wrocław, Poland

e-mail: malgorzata.jezowska-bojczuk@chem.uni.wroc.pl

A. Kyzioł

Faculty of Chemistry, Jagiellonian University, R. Ingardena 3,

30-060 Kraków, Poland
Keywords Methotrexate - Copper(II) complexes · Plasmid DNA damage $\cdot$ Cytotoxic studies

\section{Introduction}

Methotrexate (MTX, (2S)-2-[(4-\{[(2,4-diaminopteridin-6yl)methyl](methyl)amino \}benzoyl)amino]pentanedioic acid) is a folic acid antagonist and it has a therapeutic effect on many types of cancer cells. It is currently widely used as a major chemotherapeutic agent for human malignancies, such as acute lymphoblastic leukemia, lymphoma, osteosarcoma, and also breast, lung, head, and neck cancers (Yoon et al., 2010). In the body, MTX is taken up by cells and tissues and then immediately metabolized to polyglutamate derivatives. Polyglutamates block the synthesis of purines and pyrimidines by inhibiting dihydrofolate reductase and several other folate-dependent enzymes. This blocking results in the disruption of DNA biosynthesis and is the basis of MTX chemotherapeutic action (Chibber et al., 2012). Tumor cells require about tenfold higher concentration of thymidine triphospate than healthy cells, and therefore they are more sensitive to the effects of antifolates (Navarro-Peran et al., 2005).

MTX is a methylated derivative of folic acid (Fig. 1). Its structure consists of a pteridine ring and dimethyl-paminobenzoic acid residue linked with glutamic acid. The coordination properties of this compound are not well characterized. Metal complexes of pteridines are rare since it is a highly $\pi$ electron-deficient heterocyclic system (Kaim et al., 1999). On the other hand, the binding properties of glutamic acid, which forms thermodynamically stable complexes with a number of metal ions, are well characterized (Sajadi, 2010; Naik et al., 2012). 


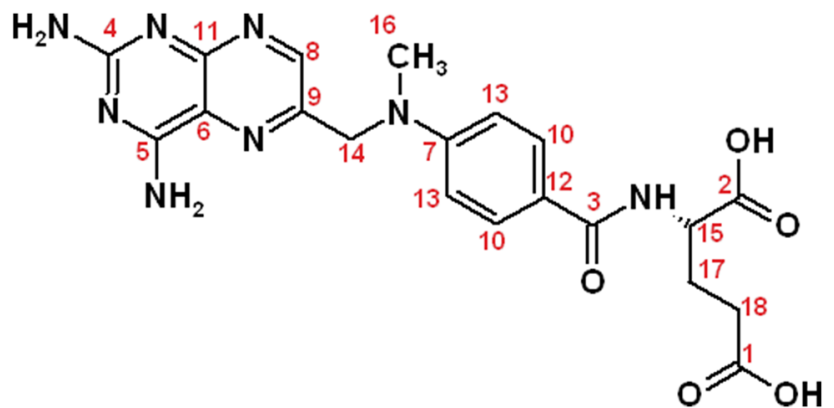

Fig. 1 The molecular formula of MTX with atom numeration scheme used for ${ }^{13} \mathrm{C}$ NMR spectra analysis

Copper is an important metal ion and an essential constituent of our biological enzyme systems. It is proven that both in inflammatory conditions and during neoplastic diseases copper plasma concentration rises from $15 \mu \mathrm{M} / \mathrm{L}$ in normal to $22-26 \mu \mathrm{M} / \mathrm{L}$ in cancerous cells (Zowczak et al., 2001). Hence, it is possible that chemotherapeutic drugs have an opportunity to interact with endogenous copper. Therefore, the aim of this work was to: (1) investigate the coordination properties of MTX toward $\mathrm{Cu}(\mathrm{II})$ ions, (2) verify the ability of this complex to generate ROS and DNA damage, and (3) establish the potential cytotoxic effect of the $\mathrm{Cu}(\mathrm{II})-\mathrm{MTX}$ complex against two cancer cell lines.

\section{Experimental}

\section{Materials}

Methotrexate, $\mathrm{CuCl}_{2} \times 6 \mathrm{H}_{2} \mathrm{O}$, TSP- $\mathrm{d}_{4}$ (trimethylsilyl propionate), $\mathrm{D}_{2} \mathrm{O}, \mathrm{DNO}_{3}, \mathrm{NaOD}$, and pUC18 plasmid DNA were obtained from Sigma-Aldrich $\mathrm{Co}$, Germany. $\mathrm{NaOH}$, $\mathrm{HCl}$, and ethylene glycol were purchased from Merck $\mathrm{KGaA}$, Germany. Calibration buffers at $\mathrm{pH}$ values 4.01 and 9.21 was received from Mettler-Toledo GmbH, Germany.

\section{Potentiometric measurements}

Potentiometric titrations of MTX and its complexes with $\mathrm{Cu}$ (II) in aqueous solution in the presence of $0.1 \mathrm{M} \mathrm{KCl}$ were performed at $298 \mathrm{~K}$ under argon atmosphere using pH-metric titrations (Metrohm, 905 Titrando). The $\mathrm{CO}_{2}$ free $\mathrm{NaOH}$ solution was used as a titrant. The samples were titrated in the $\mathrm{pH}$ region $2.0-10.5$ using a total volume of $1.5 \mathrm{~mL}$. Changes in $\mathrm{pH}$ were monitored with a combined glass- $\mathrm{Ag} / \mathrm{AgCl}$ electrode (Metrohm, Biotrode) calibrated daily by $\mathrm{HCl}$ titrations (Irving et al., 1967). Ligand concentration was $5 \times 10^{-4} \mathrm{M}$, and metal to ligand molar ratios of $1: 1$ and 1:4 were used. These data were analyzed using the SUPERQUAD program (Gans 1983). Standard deviations ( $\sigma$ values) quoted were computed by SUPERQUAD and refer to random errors.

Nuclear magnetic resonance (NMR)

${ }^{1} \mathrm{H}$ NMR and ${ }^{13} \mathrm{C}$ NMR measurements were performed on a Bruker AMX-500 instrument $\left({ }^{1} \mathrm{H}\right.$ : $\left.500 \mathrm{MHz}\right)$. TSP (trimethylsilyl propanoic acid) was used as an internal standard. Samples were prepared in $500 \mu \mathrm{D}_{2} \mathrm{O}(99.95 \%)$ and the final concentration was $10 \mathrm{mM}$ and $40 \mathrm{mM}$ for proton and carbon spectra, respectively. NMR spectra were recorded for MTX and $\mathrm{Cu}(\mathrm{II})-\mathrm{MTX}$ system at $\mathrm{pD}(\mathrm{pH}$ measured by electrode uncorrected for the isotopic effect) value 7.5, which after appropriate correction (Krężel and $\mathrm{Bal}, 2004)$ is equal to 7.4. Measurements were made for solutions at five different $\mathrm{Cu}$ (II)-MTX molar ratios 1:500 $\div 5: 500$. The $\mathrm{pD}$ of samples was adjusted by adding small volumes of concentrated $\mathrm{DNO}_{3}$ or $\mathrm{NaOD}$.

Infrared spectroscopy (IR)

The room temperature infrared powder spectra were recorded using Bruker IFS-66 FT spectrometer. The scanning range was $4,000-400 \mathrm{~cm}^{-1}$ and the resolution was $2 \mathrm{~cm}^{-1}$. Spectra of MTX alone and the Cu(II)-MTX complex were registered in a transmission mode as $\mathrm{KBr}$ pellets.

DNA strand break analysis

The ability of $\mathrm{Cu}(\mathrm{II})-\mathrm{MTX}$ complex to induce single- and/ or double-strand breaks in the absence or presence of $\mathrm{H}_{2} \mathrm{O}_{2}$ was tested with the pUC18 plasmid on $1 \%$ agarose gels containing ethidium bromide. The buffered samples (phosphate buffer, $\mathrm{pH}$ 7.4) contained combinations of DNA $(25 \mu \mathrm{g} / \mathrm{mL})$ and the components of investigated systems (metal ion and/or antibiotic, $\mathrm{H}_{2} \mathrm{O}_{2}$ ). Concentrations of each substance are given in figure captions. The metal to ligand molar ratio 1:1 was used according to the complexes stoichiometry based on the potentiometric calculations. After $1 \mathrm{~h}$ of incubation at $37^{\circ} \mathrm{C}$ in the dark, the reaction mixtures were mixed with $4 \mathrm{~mL}$ of loading buffer (bromophenol blue in $30 \%$ glycerol) and loaded on $1 \%$ agarose gels containing ethidium bromide (Sigma-Aldrich), in TBE buffer (90 mM Tris-borate, $\mathrm{pH}$ 8.0; 20 mM EDTA). Gel electrophoresis was done at a constant voltage of $4 \mathrm{~V} / \mathrm{cm}$ for $60 \mathrm{~min}$. As a control for double-strand breaks, reference plasmid samples were linearized with EcoRI endonuclease. The gels were photographed and processed with a Digital Imaging System (Syngen Biotech, Wroclaw, Poland). 
Reactive oxygen species (ROS) generation measurements

The ROS generation measurements were carried out with NDMA ( $N, N$-dimethyl-4-nitrosoaniline) and NBT (nitrotetrazolium blue chloride), a scavenger molecules commonly used in studies of hydroxyl radicals and superoxide anion generation, respectively. The experiments were followed at $25^{\circ} \mathrm{C}$ on a Cary 60 spectrophotometer. The solutions of NDMA and NBT at final concentrations $20 \mu \mathrm{M}$ were added to the samples containing $50 \mu \mathrm{M}$ $\mathrm{Cu}(\mathrm{II}), \mathrm{MTX}$ and $\mathrm{Cu}(\mathrm{II})-\mathrm{MTX}$, in the presence of $50 \mu \mathrm{M}$ $\mathrm{H}_{2} \mathrm{O}_{2}$, at pH 7.4 (0.2 $\mathrm{M}$ phosphate buffer). The generation of singlet oxygen was tested by gel electrophoresis in conditions described above ("DNA strand break analysis" section) with an extra addition of $\mathrm{NaN}_{3}$ (singlet oxygen scavenger (Franco et al., 2007)) at final concentration $40 \mathrm{mM}$.

\section{Cytotoxic assay}

\section{Cell lines and culture conditions}

CT26 cell line (mouse colon carcinoma, morphology: fibroblast, ATCC: CRL-2638) and A549 cell line (human lung adenocarcinoma, morphology: epithelial, ATCC: CCL-185) were obtained from professor Luis G. Arnaut group (Chemistry Department, University of Coimbra, Portugal). Cells were cultured in flasks in Dulbecco's Modified Eagle Medium (DMEM) without phenol red, with $10 \%$ fetal bovine serum (FBS) and with $1 \%$ streptomycin/penicillin at $37{ }^{\circ} \mathrm{C}$ and $5 \% \mathrm{CO}_{2}$ in a humidified atmosphere. Cells were passaged at preconfluent densities, using a solution containing $0.05 \%$ trypsin and $0.5 \mathrm{mM}$ EDTA. All the cell culture fluids were purchased from IMMUNIQ (Poland).

\section{Cytotoxicity study}

The cytotoxic activity in vitro was evaluated by the MTT assay. The assay was carried out according to the wellknown protocol (Slater et al., 1963). For the screening experiments, exponentially growing cells were harvested and plated in 96-well plates at a concentration of $1 \times 10^{4}$ cells/well. After $24 \mathrm{~h}$ of incubation at $37^{\circ} \mathrm{C}$ under humidified $5 \% \mathrm{CO}_{2}$ allowing cell attachment, the cells in the wells were treated with tested compounds at various concentrations in the range from 1 to $100 \mu \mathrm{M}$. The compounds were predissolved in phosphate buffer ( $\mathrm{pH} 7.4)$ and diluted in the respective medium with $1 \%$ FBS.

Two different protocols of cytotoxicity evaluation were performed. In the first approach cells were treated with
$200 \mu \mathrm{L}$ of tested samples: $\mathrm{CuCl}_{2}$, MTX, Cu(II)-MTX, and cisplatin for $4 \mathrm{~h}$ at $37{ }^{\circ} \mathrm{C}$ under conditions of $5 \% \mathrm{CO}_{2}$. Then, solutions were removed, cells were washed with PBS (phosphate buffered saline, IMMUNIQ, Poland) and fresh relevant medium was added. Cells were incubated for $24 \mathrm{~h}$ at standard conditions and then cytotoxicity was estimated once more. Whereas, in the second approach cells were incubated with various concentrations of tested samples diluted in DMEM containing $1 \%$ FBS for $24 \mathrm{~h}$ in standard conditions. After that time surviving fraction was determined by MTT assay.

\section{MTT assay}

Briefly, a solution of 3-(4,5-dimethylthiazo1-2-y1)-2,5diphenyltetrazolium bromide (MTT, Sigma) was prepared at $5 \mathrm{mg} / \mathrm{mL}$ in PBS and was diluted 1:10 in DMEM without FBS. $200 \mu \mathrm{L}$ of this solution was added to each well. After $4 \mathrm{~h}$ of incubation at $37{ }^{\circ} \mathrm{C}$ in a humidified incubator with $5 \% \mathrm{CO}_{2}$, the medium/MTT mixtures were removed, and the formazan crystals formed by the mitochondrial dehydrogenase activity of vital cells were dissolved in $100 \mu \mathrm{L}$ of DMSO: $\mathrm{CH}_{3} \mathrm{OH}$ dilution (1:1). The absorbance of soluble product was read with a microplate reader (Infinite $200 \mathrm{M}$ PRO NanoQuant, Tecan, Switzerland) at $565 \mathrm{~nm}$.

\section{Data analysis}

Cell viability was calculated using cells treated with DMEM containing $1 \%$ FBS as control. Cell surviving fraction (\%) was calculated using the formula: $S / S_{0}$ $(\%)=\left[\operatorname{abs}_{565 \mathrm{~nm}}\right.$ of treated cells/abs ${ }_{565 \mathrm{~nm}}$ of untreated cells (control) $] \times 100$. Each experiment was done in triplicate and was repeated at least twice. The inhibitory concentration (IC) values were calculated from a doseresponse curve. $\mathrm{IC}_{50}$ values were determined from the fitting curve by calculating the concentration of agent that reduced the surviving fraction of treated cells by $50 \%$, compared to control cells. $\mathrm{IC}_{50}$ data are expressed as mean values \pm standard deviation (SD) and they are the average of two independent experiments, done in triplicate.

\section{Fluorescence microscopy}

Viable and dead cells were detected by staining with AO $(5 \mathrm{mg} / \mathrm{L})$ and PI $(5 \mathrm{mg} / \mathrm{L})$ for $20 \mathrm{~min}$ and examined using fluorescence- inverted microscope (Olympus IX51, Japan) with an excitation filter of 470/20 nm. Photographs of the cells after treatment with the tested compounds were taken under magnification $20.00 \times$. 
Table 1 Potentiometric parameters for MTX and its $\mathrm{Cu}(\mathrm{II})$ complexes

\begin{tabular}{lrl}
\hline Ligand/complex & \multicolumn{1}{c}{$\log \beta^{\mathrm{a}}$} & $\mathrm{p} K_{\mathrm{a}}^{\mathrm{b}}$ \\
\hline $\mathrm{H}_{3} \mathrm{~L}$ & $13.10(4)$ & 2.89 \\
$\mathrm{H}_{2} \mathrm{~L}$ & $10.21(3)$ & 4.56 \\
$\mathrm{HL}$ & $5.65(3)$ & 5.65 \\
$\mathrm{CuHL}$ & $8.82(6)$ & - \\
$\mathrm{CuL}$ & $4.01(3)$ & 4.81 \\
$\mathrm{CuH}_{-1} \mathrm{~L}$ & $-2.32(3)$ & 6.33
\end{tabular}

${ }^{\mathrm{a}} \mathrm{nH}^{+}+\mathrm{L}^{\mathrm{m}-} \leftrightarrow \mathrm{H}_{\mathrm{n}} \mathrm{L}$, statistical errors on the last digits of stability constant are given in parentheses. Overall stability constant $(\beta)$ expressed by equation $\beta_{\mathrm{HnL}}=\left[\mathrm{H}_{\mathrm{n}} \mathrm{L}^{(\mathrm{m}-\mathrm{n})-}\right] /\left[\mathrm{H}^{+}\right]\left[\mathrm{L}^{\mathrm{m}-}\right]$ describes a reaction

${ }^{\mathrm{b}}$ Deprotonation constant ( $\left.\mathrm{p} K \mathrm{a}\right)$ expressed by equation $\mathrm{p} K \mathrm{a}=\log \beta$ $\left(\mathrm{H}_{\mathrm{n}} \mathrm{L}^{(\mathrm{m}-\mathrm{n})-}\right)-\log \beta\left(\mathrm{H}_{\mathrm{n}-1} \mathrm{~L}^{(\mathrm{m}-\mathrm{n}+1)-}\right)$

\section{Results and discussion}

The acid-base chemistry of methotrexate

MTX molecule contains a 2,4-diaminopteridine ring and $\mathrm{N}, \mathrm{N}$-dimethyl-p-aminobenzoic acid residue linked with glutamic acid by a peptide bond (Fig. 1). It exists in water solution in a fully protonated form as a $\mathrm{H}_{3} \mathrm{~L}$ ligand. The acid-base properties of the moieties, which can be deprotonated with a rise of $\mathrm{pH}$ value, were determined using potentiometric measurements (Table 1). The first two obtained $\mathrm{p} K_{\mathrm{a}}$ values: 2.89 and 4.56 correspond to the deprotonation of carboxylic groups from glutamic acid, $\alpha-\mathrm{COOH}$ and $\gamma-\mathrm{COOH}$, respectively (Poe, 1973, 1977; Meloun et al., 2010). The highest value of $\mathrm{p} K_{\mathrm{a}}=5.65$ corresponds to the deprotonation process of the heterocyclic nitrogen $(\mathrm{N} 1) \mathrm{H}^{+}$from the pteridine ring. The resulting $\mathrm{p} K_{\mathrm{a}}$ values are quite consistent with the literature data. They have been first determined by Poe (1973) using potentiometric and spectrophotometric titrations, as 3.36, 4.70 , and 5.71, respectively.

Investigation of the $\mathrm{Cu}(\mathrm{II})-$ methotrexate coordination mode

In order to obtain insight into the binding mode of MTX, the complex formation processes were studied by potentiometry, IR, and NMR spectroscopic techniques. These methods all together enabled verification of the type of donor atoms bound to $\mathrm{Cu}(\mathrm{II})$ ions and determination of the stability constants (Table 1 ). In the investigated $\mathrm{pH}$ range three monomeric complexes are formed: $\mathrm{CuHL}, \mathrm{CuL}$, and $\mathrm{CuH}_{-1} \mathrm{~L}$. Stability constants for bis-ligand complexes could not be established with certainty, therefore they were excluded from the accepted model. The binding process

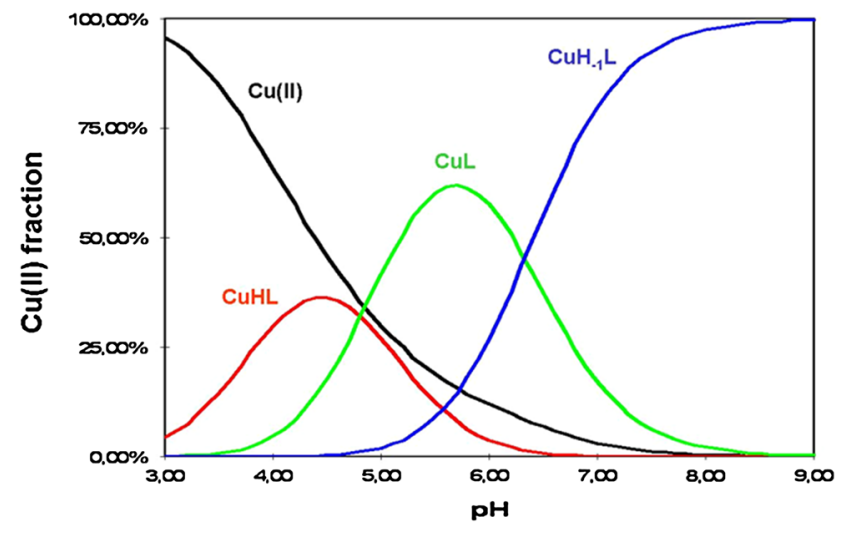

Fig. 2 Species distribution diagram for the $\mathrm{Cu}(\mathrm{II})-\mathrm{MTX}$ system

starts at $\mathrm{pH} 3.0$ with the appearance of a CuHL form, as shown in the distribution diagram (Fig. 2). Considering the acid-base properties of the ligand, it is clear that in the presence of copper(II) ion the MTX molecule simultaneously loses two protons. The groups with the lowest $\mathrm{p} K_{\mathrm{a}}$ values are the $\alpha$-carboxyl and $\gamma$-carboxyl ones. It can be assumed that the $\mathrm{Cu}(\mathrm{II})$ ion binds to the oxygen atoms from both of them. With the rise of $\mathrm{pH}$, the species distribution diagram reveals the occurrence of a new $\mathrm{CuL}$ form which reaches the maximum concentration at $\mathrm{pH} \sim 5$.8. In that $\mathrm{pH}$ range deprotonation of $(\mathrm{N} 1) \mathrm{H}^{+}$nitrogen takes place probably without its participation in the binding process. The last species, $\mathrm{CuH}_{-1} \mathrm{~L}$, is formed due to the forced dissociation of amide moiety caused by metal ion binding to this fragment of the studied molecule.

These assumptions are supported by the NMR and IR results. Using NMR spectroscopy we could verify the type of donor atoms bound to the metal ion in solution. As in a number of other instances (Bertini and Pierattelli, 2004; Otting, 2010), also in this case the coordination of the paramagnetic cation causes a significant decrease of the intensity or even disappearance of the signals derived from the neighboring carbon atoms. Thus, the interaction of MTX with small amounts of Cu(II) solution (M:L 1:500) also results in vanishing of both carboxylic carbons and $\mathrm{C}_{\alpha}$ signals from glutamyl residue (Fig. 3). The remaining peaks from glutamic carbon atoms and the neighboring $\mathrm{C}_{\mathrm{C}=\mathrm{O}}$ have a lower intensity. These findings support the model of coordination $\left\{\alpha-\mathrm{COO}^{-}, \gamma-\mathrm{COO}^{-}\right.$, and $\left.\mathrm{N}_{\text {amide }}\right\}$ deduced above (Fig. 4). The chemical shift values of MTX carbon atoms are collected in Table 2.

Interestingly, the intensity of all ${ }^{13} \mathrm{C}$ NMR signals from the pteridine ring also slightly decreases. The participation of this part of the molecule in the binding process does not fit the expected model. There could be one explanation for this phenomenon connected with the stacking interaction. The self-association of heterocyclic aromatic compounds 
Fig. $3{ }^{13} \mathrm{CNMR}$ spectra of MTX and $\mathrm{Cu}(\mathrm{II})-\mathrm{MTX}$ solutions at $\mathrm{pH} 7.4$

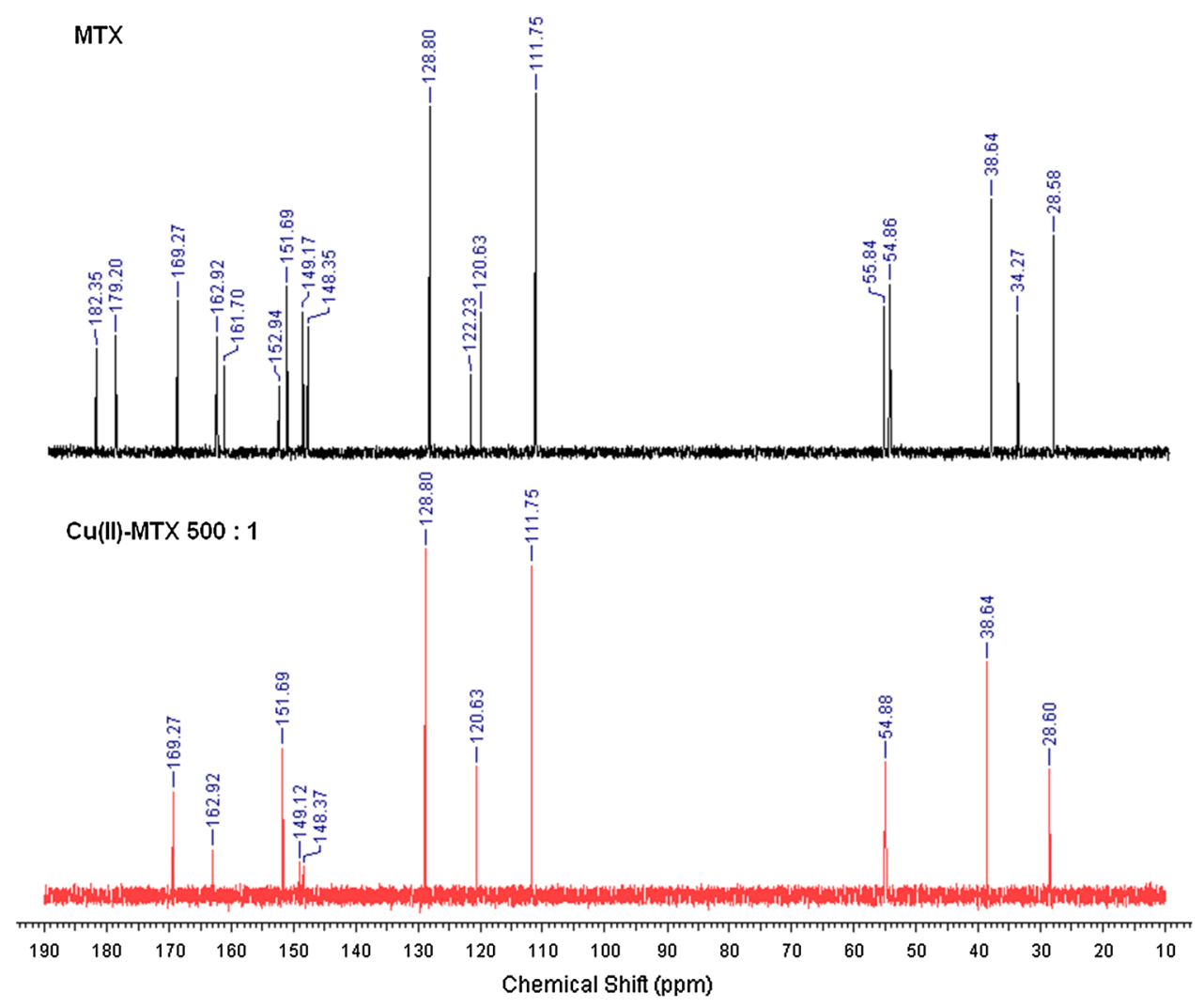

Fig. 4 The model of $\mathrm{Cu}(\mathrm{II})-$ MTX complex existing at $\mathrm{pH} 7.5$

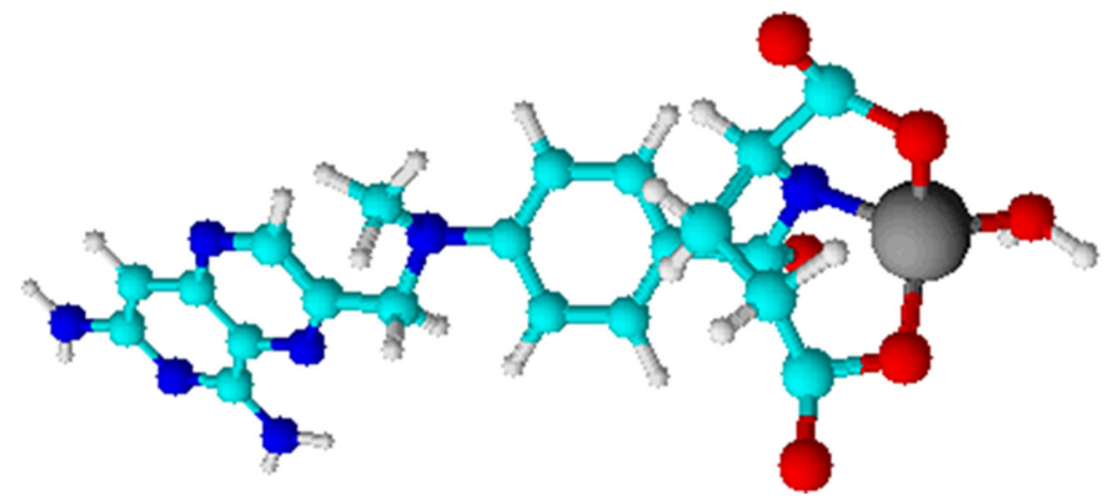

has been observed for purines and pyrimidines, structurally related to MTX (Sigel and Griesser, 2005; Mitchell and Sigel, 1978; Dunger et al., 1998). Therefore, this process can be expected in the studied case. MTX is known to aggregate, depending on the concentration and $\mathrm{pH}$. However, the investigation of folates showed that these compounds do not form higher oligomers than dimers (Poe, 1973). According to this knowledge, at the neutral $\mathrm{pH}$ an MTX dimer consists of two molecules in a fully "stretched out" configuration. Consequently, both pteridine and $p$-aminobenzoate rings may participate in stacking interactions in a head-to-tail arrangement (Poe, 1973). This circumstance would be very helpful in the explanation of the disappearance of ${ }^{13} \mathrm{C}$ NMR signals from pteridine moiety in the course of the present research. Chemical shifts are very sensitive to the environment. Looking at the proposed dimer structure, it is clearly seen that the pteridine ring is localized exactly above the $p$-aminobenzoate ring linked with glutamic acid (Fig. 5). Therefore, binding of copper(II) ions to carboxyl groups and amide nitrogen reduces the intensity of the signals of both the adjacent carbon atoms and pteridinic atoms.

The results obtained from FTIR experiments also support the proposed coordination mode. When comparing the solid state spectra of MTX and the Cu(II)-MTX system (Fig. S1), the most pronounced changes were recorded in the range of asymmetric stretching vibrations of $\mathrm{COO}^{-}$ groups $\left(1700-1600 \mathrm{~cm}^{-1}\right)$. These bands are not visible in the complex spectrum. Returning to the analysis of the ligand data, it is supposed that MTX exists in a zwitterionic 
Table 2 The ${ }^{13} \mathrm{C}$ NMR chemical shifts for MTX solution at $\mathrm{pH} 7.4$

\begin{tabular}{llll}
\hline Carbon & $\delta[\mathrm{ppm}]$ & Carbon & $\delta[\mathrm{ppm}]$ \\
\hline $\mathrm{C}^{1}$ & 182.3 & $\mathrm{C}^{10}$ & 128.8 \\
$\mathrm{C}^{2}$ & 179.2 & $\mathrm{C}^{11}$ & 122.2 \\
$\mathrm{C}^{3}$ & 169.3 & $\mathrm{C}^{12}$ & 120.6 \\
$\mathrm{C}^{4}$ & 162.9 & $\mathrm{C}^{13}$ & 111.7 \\
$\mathrm{C}^{5}$ & 161.7 & $\mathrm{C}^{14}$ & 55.8 \\
$\mathrm{C}^{6}$ & 152.9 & $\mathrm{C}^{15}$ & 54.9 \\
$\mathrm{C}^{7}$ & 151.7 & $\mathrm{C}^{16}$ & 38.6 \\
$\mathrm{C}^{8}$ & 149.2 & $\mathrm{C}^{17}$ & 34.3 \\
$\mathrm{C}^{9}$ & 148.3 & $\mathrm{C}^{18}$ & 28.6 \\
\hline
\end{tabular}

Assignments were made on the basis of Spectrum Database of Organic Compounds

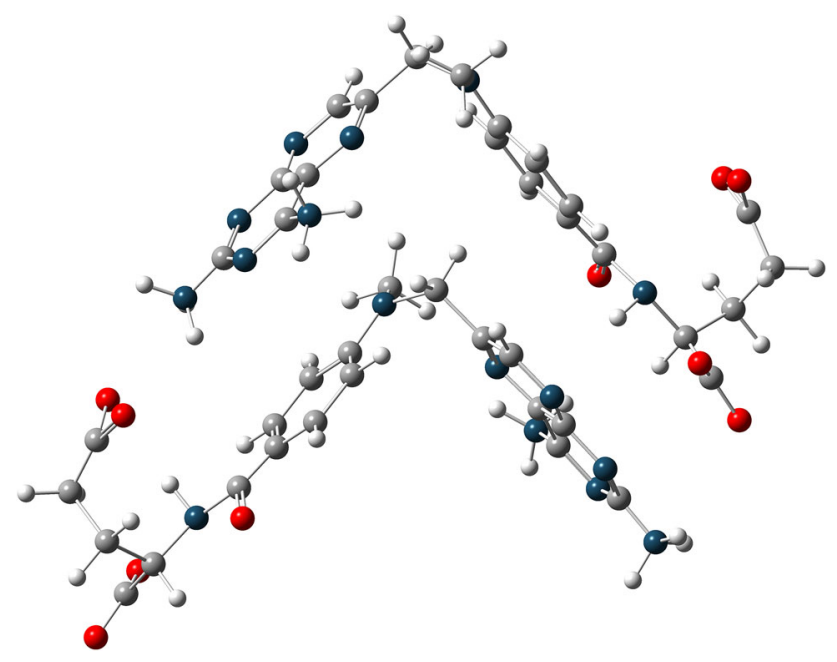

Fig. 5 Proposed structure for MTX dimer on the basis of crystal data

form with a positive charge at two pteridine amino groups and a negative charge at carboxylate anions. An absorption band above $1700 \mathrm{~cm}^{-1}$ characteristic for the $\mathrm{COOH}$ group was not observed. However, there is a band in the range of $1690-1640 \mathrm{~cm}^{-1}$ which corresponds to the asymmetric stretching vibration of the $\mathrm{COO}^{-}$moieties. Simultaneously, the band originating from the amino group vibrations does not appear. Instead, overlapped bands can be seen derived from the stretch vibration of carboxylate anions and asymmetric deformation of $-\mathrm{NH}_{3}{ }^{+}$. Such zwitterionic structure can facilitate the coordination of positive copper ion to the negative carboxylates.

DNA damage and ROS generation by the $\mathrm{Cu}(\mathrm{II})-\mathrm{MTX}$ system

In order to investigate the nuclease activity of the copper(II) complexes with MTX, pUC18 plasmid was used as the DNA substrate, and the resulting products were analyzed by an agarose-gel electrophoresis method. The cleavage activity was determined by measuring the conversion of supercoiled plasmid DNA (form I) to open-circular DNA (form II) or linear DNA (form III). The initial experiments show that the studied drug neither alone (Fig. 6, lanes 3,9) nor in the presence of hydrogen peroxide (lanes 6,12 ) is able to damage the DNA, regardless of the ligand concentration. Although $\mathrm{Cu}(\mathrm{II})$ ions alone (lanes 2, 8) and complexed (lanes 4, 10) yield some increase in the open-circular form II, significant changes in the plasmid structure are observed in the presence of $\mathrm{H}_{2} \mathrm{O}_{2}$ (lanes $5,7,11,13$ ). The obtained results demonstrate that complex $-\mathrm{H}_{2} \mathrm{O}_{2}$ (lanes 11 and 13) is the most efficient in plasmid degradation. As shown in Fig. 7, the $\mathrm{Cu}(\mathrm{II})-\mathrm{MTX}$ $\mathrm{H}_{2} \mathrm{O}_{2}$ system causes the cleavage of supercoiled DNA to its open-circular (II) and linear (III) form in a wide concentration range (from $5 \mu \mathrm{M}$ to $1 \mathrm{mM}$ ). Moreover, these effects are accompanied by cutting the plasmid into shorter polynucleotide fragments, which is particularly evident on lanes 7 and 9. The quantity of the form II is in these cases negligible and streaks are the most visible. At a twice lower concentration of hydrogen peroxide, the plasmid destruction process is identical.

In order to gain some insight into the mechanism by which the complex $-\mathrm{H}_{2} \mathrm{O}_{2}$ system induces DNA cleavage, the ability to generate ROS was investigated. Most of the studied $\mathrm{Cu}$ (II) complexes have caused single- and doublestrand DNA scissions by the oxidative mechanism in the presence of endogenous amounts of hydrogen peroxide (Suntharalingam et al., 2012; de Hoog et al., 2007; Devereux et al., 2007; Szczepanik et al., 2002; JeżowskaBojczuk et al., 2002). It has often been evident that the presence of an antibiotic enhanced the oxidative activity of $\mathrm{Cu}$ (II) ions, and the resulting complex exhibited much higher potency toward ROS induction (Gaggelli et al., 2010; Balenci et al., 2009). The hydroxyl radicals detection is performed by monitoring the NDMA characteristic band at $440 \mathrm{~nm}$ on the electronic spectra. Generation of the $\mathrm{OH}$ radicals causes the decrease in the intensity of this band and can be measured in a time-dependent mode. The ${ }^{\cdot} \mathrm{OH}$ induction by the complex- $\mathrm{H}_{2} \mathrm{O}_{2}$ system was investigated in the conditions of gel electrophoresis experiments $(50 \mu \mathrm{M}$ concentration of both the complex and $\mathrm{H}_{2} \mathrm{O}_{2}$ ). However, only a slight decrease of the NDMA band was observed. The ability to generate superoxide anion by the complex$\mathrm{H}_{2} \mathrm{O}_{2}$ system was also examined by performing a similar test with another reporter molecule-NBT. Likewise, the investigated system failed to induce this type of radicals. The next experiment was carried out using gel electrophoresis by adding sodium azide (singlet oxygen scavenger) to the reaction mixture. This procedure did not cause the inhibition of the cleavage reaction either. 


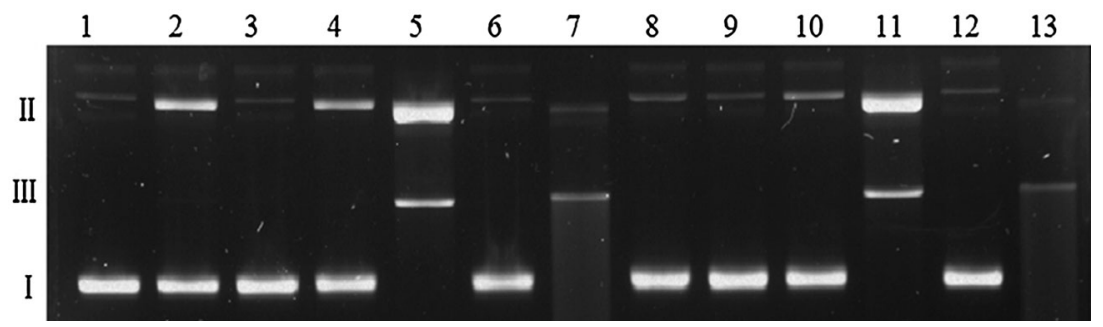

Fig. 6 Agarose gel electrophoresis of pUC18 plasmid cleavage by MTX, $\mathrm{CuCl}_{2}$, and $\mathrm{Cu}(\mathrm{II})-\mathrm{MTX}(1: 1)$. Lane 1 -untreated plasmid, lane 2-100 $\mu \mathrm{M} \mathrm{CuCl}_{2}$, lane 3-100 $\mu \mathrm{M} \mathrm{MTX}$, lane 4-100 $\mu \mathrm{M}$ $\mathrm{Cu}(\mathrm{II})-\mathrm{MTX}$, lane 5-100 $\mu \mathrm{M} \mathrm{CuCl} \mathrm{Cu}_{2}+50 \mu \mathrm{M} \mathrm{H}_{2} \mathrm{O}_{2}$, lane 6$100 \mu \mathrm{M} \quad \mathrm{MTX}+50 \mu \mathrm{M} \quad \mathrm{H}_{2} \mathrm{O}_{2}$, lane 7-100 $\mu \mathrm{M} \quad \mathrm{Cu}(\mathrm{II})-$
$\mathrm{MTX}+50 \mu \mathrm{M} \quad \mathrm{H}_{2} \mathrm{O}_{2}$, lane $8-50 \mu \mathrm{M} \quad \mathrm{CuCl}_{2}$, lane 9-50 $\mu \mathrm{M}$ $\mathrm{MTX}$, lane $10-50 \mu \mathrm{M} \quad \mathrm{Cu}(\mathrm{II})-\mathrm{MTX}$, lane $11-50 \mu \mathrm{M}$ $\mathrm{Cu}(\mathrm{II})+50 \mu \mathrm{M} \mathrm{H}_{2} \mathrm{O}_{2}$, lane $12-50 \mu \mathrm{M} \mathrm{MTX}+50 \mu \mathrm{M} \mathrm{H}_{2} \mathrm{O}_{2}$, lane $13-50 \mu \mathrm{M} \mathrm{Cu}(\mathrm{II})-\mathrm{MTX}+50 \mu \mathrm{M} \mathrm{H}_{2} \mathrm{O}_{2}$

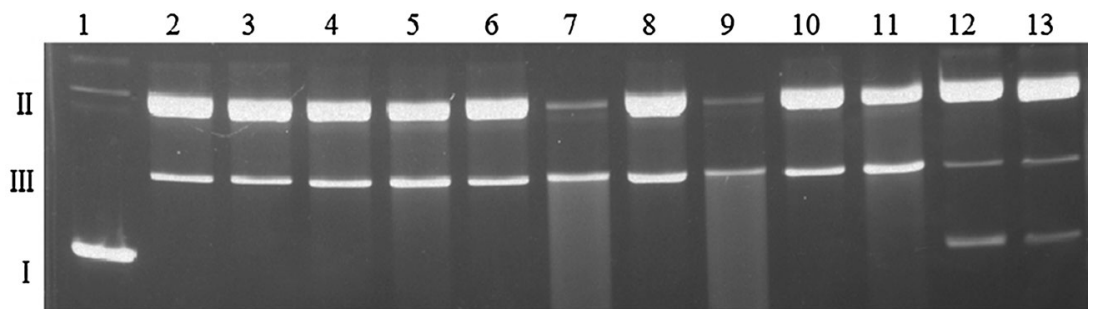

Fig. 7 Agarose gel electrophoresis of pUC18 plasmid cleavage by $\mathrm{Cu}(\mathrm{II})-\mathrm{MTX}(1: 1)$ in the presence of $50 \mu \mathrm{M} \mathrm{H}_{2} \mathrm{O}_{2}$. Lane 1-untreated plasmid; Even lanes: $+\mathrm{CuCl}_{2}$ in concentrations: $1 \mathrm{mM}, 500 \mu \mathrm{M}$,

Taken together, the obtained results suggest that the single- and double-stranded DNA cleavage mediated by complex- $\mathrm{H}_{2} \mathrm{O}_{2}$, does not occur by an oxidative mechanism. On the other hand, the same reactions performed without hydrogen peroxide do not result in plasmid degradation (Fig. 6, lanes 4, 10). This led us to propose that most probably the active species is copper-oxene or coppercoordinated hydroxyl radical (Sigman et al., 1991; Baron et al., 1936). The reactive species remain tightly bound to copper(II), thus preventing them from being deactivated by radical scavengers. A copper-oxene or a resonance hybrid of a copper(II)-hydroxyl radical species generates a deoxyribose-centered radical by $\mathrm{C}-1$ hydrogen abstraction (Sigman et al., 1991; Baron et al., 1936), and is probably responsible for plasmid DNA cleavage in the studied case.

In vitro cytotoxic studies

The anticancer activity of $\mathrm{MTX}, \mathrm{CuCl}_{2}, \mathrm{Cu}$ (II)-MTX, and cisplatin against two selected cell lines: mouse colon carcinoma (CT26) and human lung adenocarcinoma (A549) were investigated. The evaluation of the cytotoxic activity of the compounds was carried out by the MTT assay, based on the ability of mitochondrial dehydrogenases in the viable cells to cleave the tetrazolium rings of MTT and to form dark blue membrane-impermeable crystals of formazan. The surviving fraction was determined by the
$100 \mu \mathrm{M}, 50 \mu \mathrm{M}, 25 \mu \mathrm{M}, 5 \mu \mathrm{M}$; Odd lanes: $+\mathrm{Cu}(\mathrm{II})-\mathrm{MTX}$ at the same, appropriate concentrations

Table $3 \mathrm{IC}_{50}$ values for $\mathrm{MTX}, \mathrm{CuCl}_{2}, \mathrm{Cu}(\mathrm{II})-\mathrm{MTX}$, and cisplatin against CT26 and A549 cell lines after 4 and $24 \mathrm{~h}$ of incubation

\begin{tabular}{|c|c|c|c|c|}
\hline & \multicolumn{4}{|c|}{$\mathrm{IC}_{50}$ values $[\mu \mathrm{M}]^{\mathrm{a}}$} \\
\hline & \multicolumn{2}{|l|}{$4 \mathrm{~h}$} & \multicolumn{2}{|l|}{$24 \mathrm{~h}$} \\
\hline & СТ26 & A549 & СТ26 & A549 \\
\hline MTX & $258 \pm 78$ & $348 \pm 32$ & $460 \pm 23$ & $485 \pm 12$ \\
\hline $\mathrm{CuCl}_{2}$ & $360 \pm 52$ & $459 \pm 32$ & $423 \pm 32$ & $481 \pm 11$ \\
\hline $\mathrm{Cu}(\mathrm{II})-\mathrm{MTX}$ & $135 \pm 17$ & $151 \pm 12$ & $1022 \pm 172$ & $188 \pm 52$ \\
\hline Cisplatin & $2200 \pm 20$ & $3150 \pm 450$ & $4990 \pm 670$ & $3850 \pm 430$ \\
\hline
\end{tabular}

$\mathrm{IC}_{50}=$ concentration of drug required to inhibit growth of $50 \%$ of the cancer cells (Strohfeldt et al., 2008)

${ }^{\text {a }}$ Data are mean \pm SD of three replicates each

relationship between the optical absorbance of dissolved formazan into a colored solution and the number of viable cell.

The $\mathrm{IC}_{50}$ values were derived from dose-response curves and are summarized in Table 3. Cytotoxic study in vitro revealed that $\mathrm{Cu}(\mathrm{II})-\mathrm{MTX}$ exhibits considerable toxicity toward both tested cell lines. The $\mathrm{IC}_{50}$ values obtained for the complex were in most cases lower than those for MTX and $\mathrm{CuCl}_{2}$. Generally, the greatest effect was observed on both cell lines after $4 \mathrm{~h}$ of incubation with the tested samples (Table 3). While after $24 \mathrm{~h}$ the impact 
Fig. 8 The selected photos (magnification $\times 20.00$, bar $50 \mu \mathrm{m})$ of CT26 and A549cells after treated with the tested compounds $(0.05 \mathrm{mM})$ for $24 \mathrm{~h}$. The green cells with normal morphology are viable ones $(\mathrm{AO}+)$, while round red cells are dead (PI+)
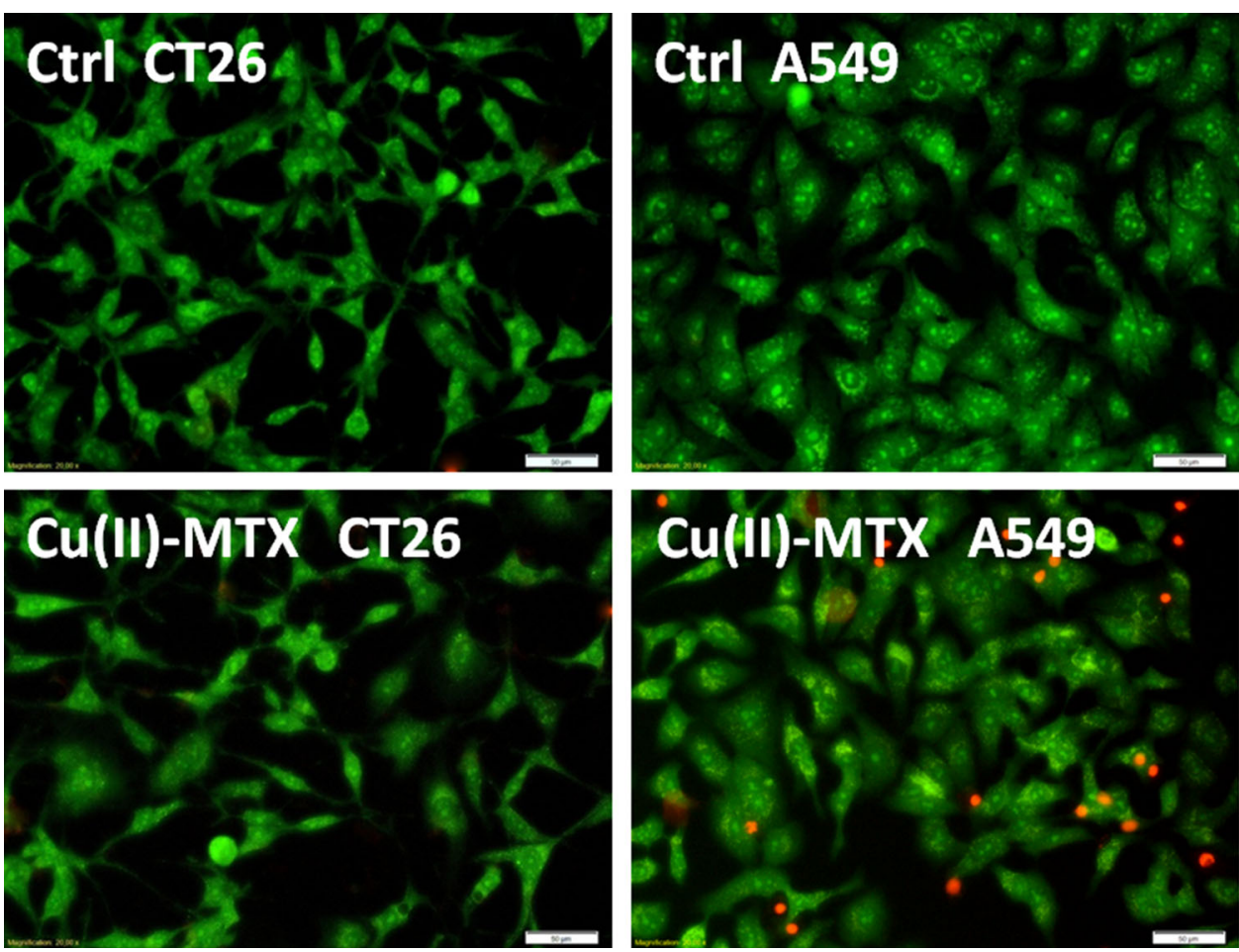

of the complex on A549 line was similar $\left(\mathrm{IC}_{50}: 188 \mu \mathrm{M}\right.$ ), in the case of CT26 line the cytotoxic effect was dramatically lower $\left(\mathrm{IC}_{50}: 1022 \mu \mathrm{M}\right)$. These results indicate that A459 line is more sensitive for $\mathrm{Cu}$ (II)-MTX than CT26 cell line. It is noteworthy that all the tested compounds showed a significantly better anticancer activity than cisplatin (Table 3). Selected photographs of CT26 and A549 cell lines treated with the tested compounds are provided in Fig. 8. Cell viability was examined by counting the dead and alive cells stained with two fluorescent dyes. Accordingly, green cells with normal nuclei were treated as viable cells $(\mathrm{AO}+)$, while the red ones as dead (PI+). As can be noticed, $\mathrm{Cu}(\mathrm{II})-\mathrm{MTX}$ caused a significant reduction only in the surviving fraction of A549 cell line (after $24 \mathrm{~h}$ of incubation time). This means that the investigated complex may exhibit selective biological activity toward only specific tumors. These studies indicate that $\mathrm{Cu}(\mathrm{II})-\mathrm{MTX}$ exhibits biological activity toward specific cell lines and the cytotoxicity level is time dependent. The obtained results are preliminary and further investigations are needed to understand the molecular mechanism of cytotoxicity.

\section{Conclusions}

It was demonstrated that MTX interacts with $\mathrm{Cu}(\mathrm{II})$ ions and in aqueous solution it forms three monomeric complexes in a wide $\mathrm{pH}$ range. Moreover, basic biological in vitro studies were performed. In the presence of hydrogen peroxide the $\mathrm{Cu}(\mathrm{II})-\mathrm{MTX}$ system displays nuclease activity, almost completely cleaving DNA. Most probably, the responsibility for the plasmid degradation processes may be attributed to the copper-oxene or coppercoordinated hydroxyl radical. Investigations of the anticancer activity showed that the complex generally displays higher cytotoxicity in vitro than the ligand and metal ion separately and is more selective against A459 cell line. As MTX is used in the treatment of lung cancer, our investigations demonstrated that complexation of MTX by $\mathrm{Cu}$ (II) ions results in its higher cytotoxicity. Moreover, in comparison to cisplatin, the $\mathrm{Cu}(\mathrm{II})-\mathrm{MTX}$ system shows superior anti-tumor effects. MTX interacts with copper(II) ions forming complexes which display high DNA-cleaving propensity and promising cytotoxicity. The results presented herein can be helpful in the search for new cytostatic substances.

Acknowledgments The research was supported by the Wroclaw Research Center EIT+ under the Project "Biotechnologies and advanced medical technologies - BioMed" (POIG 01.01.02-02-003/ 08-00) financed from the European Regional Development Fund (Operational Programme Innovative Economy, 1.1.2). The cytotoxic investigations were carried out with the equipment purchased, thanks to the financial support of the European Regional Development Fund in the framework of the Polish Innovation Economy Operational Program (Contract No. POIG.02.01.00-12-023/08).

Conflict of interest The authors declare that they have no conflict of interest. 
Open Access This article is distributed under the terms of the Creative Commons Attribution License which permits any use, distribution, and reproduction in any medium, provided the original author(s) and the source are credited.

\section{References}

Balenci D, Bonechi G, D’Amelio N, Gaggelli E, Gaggelli N, Molteni E, Valensin G, Szczepanik W, Dziuba M, Święcicki G, Jeżowska-Bojczuk M (2009) Structural features and oxidative stress towards plasmid DNA of apramycin copper complex. Dalton Trans 7:1123-1130

Baron ESG, DeMeio RH, Klemperer F (1936) Studies on biological oxidations: V. Copper and hemochromogens as catalysts for the oxidation of ascorbic acid. The mechanism of the oxidation. J Biol Chem 112:625-640

Bertini I, Pierattelli R (2004) Copper(II) proteins are amenable for NMR investigations. Pure Appl Chem 76:321-333

Chibber S, Hassan I, Farhan M, Naseem I (2012) Light-mediated interaction of methotrexate with transition metal $\mathrm{Cu}(\mathrm{II})$. Med Chem Res 21:2379-2387

de Hoog P, Boldron C, Gamez P, Sliedregt-Bol K, Roland I, Pitie M, Kiss R, Meunier B, Reedijk J (2007) New approach for the preparation of efficient DNA-cleaving agents: ditopic copperplatinum complexes based on 3-clip-phen and cisplatin. J Med Chem 50:3148-3152

Devereux M, Shea DO, Kellett A, McCann M, Walsh M, Egan D, Deegan C, Kedziora K, Rosair G, Muller-Bunz H (2007) Synthesis, X-ray crystal structures and biomimetic and anticancer activities of novel copper(II) benzoate complexes incorporating 2-(4'-thiazolyl)benzimidazole (thiabendazole), 2-(2pyridyl)benzimidazole and 1,10-phenanthroline as chelating nitrogen donor ligands. J Inorg Biochem 101:881-892

Dunger A, Limbach HH, Weisz K (1998) NMR studies on the selfassociation of uridine and uridine analogues. Chem Eur J 4:621-628

Franco R, Panayiotidis MI, Cidlowski JA (2007) Glutathione depletion is necessary for apoptosis in lymphoid cells independent of reactive oxygen species formation. J Biol Chem 282:30452-30465

Gaggelli E, Gaggelli N, Molteni E, Valensin G, Balenci D, Wrońska M, Szczepanik W, Nagaj J, Skała J, Jeżowska-Bojczuk M (2010) Coordination pattern, solution structure and DNA damage studies of the copper(II) complex with the unusual aminoglycoside antibiotic hygromycin B. Dalton Trans 39:9830-9837

Gans P (1983) Superquad: a new computer program for determination of stability constants of complexes by potentiometric titration. Inorg Chim Acta 79:219-220

Irving HM, Miles MG, Pettit LD (1967) A study of some problems in determining the stoicheiometric proton dissociation constants of complexes by potentiometric titrations using a glass electrode. Anal Chim Acta 38:475-488

Jeżowska-Bojczuk M, Szczepanik W, Leśniak W, Ciesiołka J, Wrzesiński J, Bal W (2002) DNA and RNA damage by $\mathrm{Cu}$ (II)-amikacin complex. Eur J Biochem 269:5547-5556
Kaim W, Schwederski B, Heilmann O, Hornung FM (1999) Coordination compounds of pteridine, alloxazine and flavin ligands: structures and properties. Coord Chem Rev 182: 323-342

Krężel A, Bal W (2004) A formula for correlating pKa values determined in $\mathrm{D}_{2} \mathrm{O}$ and $\mathrm{H}_{2} \mathrm{O}$. J Inorg Biochem 98:161-166

Meloun M, Ferencikova Z, Vrana A (2010) The thermodynamic dissociation constants of methotrexate by the nonlinear regression and factor analysis of multiwavelength spectrophotometric pH-titration data. Cent Eur J Chem 8:494-507

Mitchell PR, Sigel H (1978) A proton nuclear-magnetic-resonance study of self-stacking in purine and pyrimidine nucleosides and nucleotides. Eur J Biochem 88:149-154

Naik KBK, Raju S, Kumar BA, Rao GN (2012) Chemical speciation of binary complexes of $\mathrm{Pb}(\mathrm{II}), \mathrm{Cd}$ (II) and $\mathrm{Hg}$ (II) with L-glutamic acid in dioxan-water mixtures. Chem Spec Bioavailab 24: 241-247

Otting G (2010) Protein NMR using paramagnetic ions. Annu Rev Biophys 39:387-405

Navarro-Peran E, Cabezas-Herrera JF, Garcia-Canvos F, Durrant MC, Thorneley RNF, Rodriguez-Lopez JN (2005) The antifolate activity of tea catechins. Cancer Res 65:2059-2064

Poe M (1973) Proton magnetic resonance studies of folate, dihydrofolate, and methotrexate: evidence from $\mathrm{pH}$ and concentration studies for dimerization. J Biol Chem 248:7025-7032

Poe M (1977) Acidic dissociation constants of folic acid, dihydrofolic acid, and methotrexate. J Biol Chem 252:3724-3728

Sajadi SAA (2010) Metal ion binding properties of L-Glutamic Acid and L-Aspartic Acid, a comparative investigation. Nat Sci 2: $85-90$

Sigel H, Griesser R (2005) Nucleoside 5'-triphosphates: self-association, acid-base, and metal ion-binding properties in solution. Chem Soc Rev 34:875-900

Sigman DS, Kuwabara MD, Chen CB, Bruice TW (1991) Nuclease activity of 1,10-phenanthroline-copper in study of protein-DNA interactions. Methods Enzymol 208:414-433

Slater TF, Sawyer B, Strauli UD (1963) Studies on succinatetetrazolium reducase systems. III. Points of coupling of four different tetrazolium salts. Biochim Biophys Acta 77:383-393

Strohfeldt K, Tacke M (2008) Bioorganometallic fulvene-derived titanocene anti-cancer drugs. Chem Soc Rev 37:1174-1187

Suntharalingam K, Hunt DJ, Duarte AA, White AJP, Mann DJ, Vilar R (2012) A tri-copper(II) complex displaying DNA-cleaving properties and antiproliferative activity against cancer cells. Chem Eur J 18:15133-15141

Szczepanik W, Kaczmarek P, Sobczak J, Bal W, Gatner K, JeżowskaBojczuk M (2002) Copper(II) binding by kanamycin A and hydrogen peroxide activation by resulting complexes. New J Chem 26:1507-1514

Yoon SA, Choi JR, Kim JO, Shin JY, Zhang X, Kang JH (2010) Influence of reduced folate carrier and dihydrofolate reductase genes on methotrexate-induced cytotoxicity. Cancer Res Treat 42:163-171

Zowczak M, Iskra M, Torlinski L, Cofta S (2001) Analysis of serum copper and zinc concentrations in cancer patients. Biol Trace Elem Res 82:1-8 